\title{
SERGANČIOJO ELGSENOS LIGOS SUKELTOS KRIZĖS LAIKOTARPIU TEOLOGINIAI IR PSICHOLOGINIAI ASPEKTAI
}

\author{
Rūta Kučinskienė, Remigijus Oželis \\ Klaipèdos universitetas
}

\begin{abstract}
Anotacija
Šiandieninejje i produktyvuma orientuotoje kultūroje vengiama kalbèti mirties, ligos, netekčių tema. Tačiau anksčiau ar vèliau žmonès suserga, miršta, ìvairiausi praradimai lydi kiekvieno gyvenima. Kartu su šiomis patirtimis aplanko dvasinis skausmas, širdgèla, ịtampa, nerimas, baimè, pyktis. Tinkamai neišgyventi jausmai sukelia fizines, psichines ligas, savasties praradima, psichologines traumas, trukdo kurti visaverčius santykius. Dvasinè sveikata yra svarbiausias žmogaus sveikatos, gyvenimo būdo kokybès rodmuo, ji-gyvybiškai svarbi bendrai žmogaus sveikatai, susijusi su asmens būties esme, su tuo, ka žmogus vertina ir kas iš tiktuju jam rūpi. Straipsnyje analizuojant mokslinę literatūrą, interpretuojant, sisteminant informaciją, atskleidžiami liga išgyvenančio žmogaus būsenos pokyčiai psichologiniu ir teologiniu aspektais.

PAGRINDINIAI ŽODŽIAI: liga, žmogus, gyvenimas, krizè, netektys, tikejjimas.
\end{abstract}

\begin{abstract}
In today's productivity-oriented culture, topics related to death, illness, and loss are avoided. However, sooner or later people fall ill, die and various losses accompany everyone's life. These experiences come together with spiritual pain, grief, tension, anxiety, fear and anger. If not addressed properly, these feelings cause physical and mental illnesses, loss of one's identity, psychological trauma and interfere with fulfilling relationships. Spiritual health is the most important indicator of human health and the quality of life. It is also vital to the overall health of a person and is related to the essence of a human being and to what is valued and truly cherished by a particular person. This article reveals the changes in the state of a person in the presence of a disease from a psychological and theological perspective by analysing scientific literature, interpreting and systematizing information. KEY WORDS: disease, person, life, crisis, loss, faith.
\end{abstract}

\section{Ivadas}

Itvairūs pokyčiai, su kuriais susiduriame, tam tikrais atvejais mus labai stipriai veikia. Kartais užklumpa netektys ir kančia, nuo kurių negalime apsi- 
saugoti, - tai ịvairios ligos, praradimai. Ligas, krizes priimame ir išgyvename skirtingai. Patirtos asmeninès krizès, kartu išgyventos artimujų ligos kviečia nuodugniau žvelgti ị šią temą, suteikia galimybę jausti ir atjausti. Skatina gilintis, analizuoti ir palyginti, kaip religija, tikejjimas keičia žmogaus požiūrị i gyvenimą, jo vertę ir prasmę, kaip padeda išgyventi krizę, susitaikyti su esama situacija, vidinę ramybei bei stiprybei, ir kada ligoniui, jo artimiesiems reikalinga psichoterapinè pagalba.

Gyvybei pavojingų ligų, pvz., vėžio, išgyvenimas taip pat priskiriamas krizèms. „Krizès, kylančios dẻl susirgimo véžiu, gali pasireikšti ir ką tik vėži diagnozavus, ir - dažniausiai daug ūmiau - atsiradus véžio recidyvams $<\ldots>$. Jos gali atsirasti kartu su šiuo metu iškylančiomis santykių tarp žmonių problemomis, šeimoje, taip pat santykiuose su gydytojais ar aptarnaujančiu personalu. Krizès, jei tai tikrai krizès, atsiranda, kai nauja gyvenimo situacija jau nebepaneigiama“ (Kast, 2006, p. 105). Ištikus krizèms matomas glaudus mirties ir prarasto tikejjimo ryšys (Lowen, 2014, p. 177). Žmogus, kuriam nešti gyvenimo naštą dèl netikètos ligos tampa nepakeliamai sunku, neretai atsigręžia ị Dievą, ieško atsakymų, pradeda gilintis, kokią žinutę Kristus siunčia ligoniui.

Šventasis popiežius Jonas Paulius II pastebèjo, kad turi būti puoselèjamas konstruktyvus psichologijos, psichiatrijos ir religijos dialogas, siekiant atskleisti žmogaus slėpini (Pope John Paul II, 1996). Susidūrus su ligomis ir krizèmis neretai susergama depresija, kurią psichiatrai bando suvokti iš biologinès, psichologinès ir socialinès perspektyvų, o pripažistantieji dvasinį gyvenimo aspektą suvokia jo svarbą, bandant suprasti sergantijį. Kad sergančiam tikinčiajam, krikščioniui tinkamą pagalbą gali suteikti dvasinis palydètojas, ịgijęs bent minimalių medicinos, psichologijos žinių ir galintis nukreipti pas specialistą, o psichinès sveikatos specialistas - būti su juo susipažinęs ar bent jau gerbti katalikų tikejjimą (Kheriaty, Cihak, 2017, p. 67).

A ktualumas. Tema, nagrinèjanti ligą išgyvenančio žmogaus būsenos teologinius ir psichologinius apsektus, šiandien ypač aktuali. Gyvename apsupti vartotojiškos kultūros, kur neretai nenorima pripažinti baigtinumo, siekiama išlikti amžinai jaunu ir sveiku. Tačiau anksčiau ar vèliau žmonès suserga, miršta, įvairūs praradimai lydi kiekvieno gyvenimą, kartu išgyvena- 
mi prieštaringi jausmai, kuriems išreikšti mažeja erdvès - dvasinis skausmas, širdgèla, įtampa, nerimas, baimè, pyktis. Žmonès dažniau savo jausmus slopina pirkdami daiktus, gausiai valgydami ar vartodami vaistus. Neišgyventi jausmai netekties atveju lemia skaudžius padarinius: fizines, psichikos ligas, pašlijusius santykius, savasties praradimą (Polukordienè, 2008, p. 6), sunkios ligos atveju - psichologines traumas.

Proble ma ti ka. Žmogus bijo jo laukiančių sunkumų. Tačiau pečius užgriūvanti našta kartais mums gali padèti tapti tokiais, kokias skirta būti. Laimès apibrěžimo netektų ieškoti, atradus vaistus nuo dvasinio skausmo. Skausmas tai ugnis, kurioje turim sudegti ir iš naujo atgimti. Kita netekčių pusè - dovana: tinkamai įveikta, išgyventa netektis, krizė gali skatinti asmenybės augimą. Turime galimybę išmokti labiau džiaugtis kiekviena diena, geriau save pažinti, subręstame kaip asmenybès, bet tik su viena sąlyga - liga turi būti ịveikta. Tad labai svarbu atrasti jègų gyventi ir nepalūžti (Polukordienė, 2008, p. 6). Jei susidūrus su išbandymu, užklupus netektims stengiamasi kuo greičiau viską pamiršti, užgniaužiant savyje kančią ir sielvartą, nelieka vietos natūraliai kylantiems jausmams, o viskas, kas neišgyventa, skatina dar labiau nerimauti, bijoti, kyla mirties baimè. Svarbu suvokti, kad viskas, kas duota, turètų būti pakeliama, o žmogus gali jaustis ir atrodyti visaip. Esant kitų palaikymui, paramai ir supratimui, kad ịprastas gyvenimas po netekčių bei praradimų turi grịžti ị normalias vėžes (Polukordienè, 2008, p. 7), liga būtų lengviau pakeliama.

Darbo objektas - žmogaus, susidūrusio su liga, dvasinès būsenos pokyčiai psichologiniu ir teologiniu aspektais.

Darbo tikslas - atskleisti sergančio žmogaus krizinių išgyvenimų psichologinius ir teologinius aspektus.

Už d a vi n i a i : 1) aptarti žmogaus, išgyvenančio ligą, krizès bei krizinių išgyvenimų sampratą, ịžvelgti jų teigiamus aspektus, pasidomèti ligą lydinčios kančios prasme; 2) aptarti, kodèl neretai dèl ligos kaltinamas Dievas ir kas padeda išlaikyti tikèjimą.

Darbo metodai: mokslinès literatūros analizè, interpretacija, sisteminimas, krikščioniškas požiūris ị žmogų ligos akivaizdoje pateikiamas nagrinèjant Bibliją, teologinę literatūrą ir tekstus, psichologinis požiūris - analizuojant įvairių autorių pateiktą informaciją. 
Darbo teorinè reikšmè: visuomenejje vis dar vyrauja nuomonè, kad sveikata - tai tik fizinè žmogaus kūno būsena ir būklè. Siekiant ją stiprinti, derinama mityba, didinamas fizinis aktyvumas, vis dèlto reikètų atkreipti dėmesị ị tai, kad dvasinè sveikata yra svarbiausias žmogaus sveikatos, gyvenimo būdo kokybės rodmuo. Dvasinė sveikata - gyvybiškai svarbi bendrai žmogaus sveikatai, susijusi su asmens būties esme, su tuo, ką žmogus vertina ir kas iš tiktųjų jam rūpi. Ji yra žmogaus egzistencijos šerdis (Petrauskienė, Zaborskis, 2000, p. 109). Darbe aptariamas ir psichologijos, psichoterapijos, teologijos požiūris ị krizes, ištinkančias žmogų, kai jis suserga.

\section{Fizinès ir dvasinès sveikatos samprata}

Niekam ne paslaptis, kad sveikata - didžiausias turtas, tai žmonės žinojo nuo seno. Viena didžiausių žmogaus dorybių sveikatą laikẻ antikos filosofai (Zittlau ir kt., 2008, p. 8). Medicinos enciklopedijoje sveikata taip apibrěžiama: „Sveikata - tai fizinis ir dvasinis individo ir visuomenès normalumas“ (Medicinos enciklopedija, 1993, p. 305). Su sveikata ypač susijusi žmonių gerovė.

Vokiečių filosofas Arthur'as Schopenhauer'is yra pasakęs, kad sveikata dar ne viskas, tačiau jei nèra sveikatos, viskas nueina perniek (cit. iš Audickaitè, 2018, p. 6). Vis daugiau kalbama, kad sergant pašlyja ne tik fizinè, bet ir dvasinè sveikata - serga ir kūnas, ir siela. Žmogų susargdina bakterijos, virusai, grybeliniai mikroorganizmai, nelaimingi atsitikimai ir netinkamas elgesys, vidiniai konfliktai, psichologinès nuostatos. Moksliniais tyrimais nustatyta, kad nuo gyvensenos žmogaus sveikata priklauso $50 \%$, 30-40 \% - nuo supančios aplinkos, $10-15 \%$ - nuo paveldejjimo ir tik 8-10\% - nuo sveikatos apsaugos. Žmogus savo sveikatą turi stiprinti, ja rūpintis visą gyvenimą. Norint išlikti sveikam, išlaikyti gyvenimo kokybę, rekomenduojama laikytis tam tikru gyvensenos principų: sveika mityba, fizinių ir psichoemocinių galių stiprinimas, grūdinimas, fizinis lavinimas (Zittlau ir kt., 2008, p. 3-9).

Pasaulinè sveikatos organizacija rūpinasi žmonių sveikata ir siekia užtikrinti galimybę visiems žmonėms siekti geresnès gyvenimo kokybės. Remiantis Pasaulio sveikatos organizacijos apibūdinimu, sveikata - tai fizinè, protinè ir socialinė gerovè, ne vien tik ligos ar fizinès negalios nebuvimas. 
Gyvenimo kokybę lemia asmens fizinès, dvasinès ir sveikatos būklès bei nepriklausomybès lygmuo, socialinis ryšys su aplinka. Gyvenimo kokybe apibūdinama kaip individo savos pozicijos gyvenime suvokimas jo tikslų, lūkesčių, interesų, kultūros vertybių sistemoje, kurioje gyvena (Juozulynas, Čeremnych ir kt., 2005, p. 71). Lietuvoje sveikata ilgą laiką buvo siejama vien tik su medicinos pagalba. Vyravo nuomonè, kad visuomenè bus sveika, jei bus gausu gydytojų, ligoninių, vaistų. Lietuva pagal gydomosios priežiūros lovų skaičių, tenkantị vienam gyventojui, yra antra Europos Sajungoje (State of Health in the EU. Lietuva Šalies sveikatos profilis 2017, 2018, p. 14), tačiau, lyginant su kitomis Europos šalimis, jos nèra tarp pirmaujančiujų pagal kitus sveikatos rodiklius, tokius kaip vidutinė gyvenimo trukmė, sergamumas ir pan. (Medicinos enciklopedija, 1993, p. 305). Pastaraisiais metais pradèta kalbèti ir apie ligoninių tinklo, teikiamų paslaugų veiksmingumą, atsižvelgiant ị rodiklius ir gyventojų skaičių. Gyvenimo kokybę lemia daug ịvairių veiksnių ir aplinkybių.

Holistiniu požiūriu skiriamos šios sveikatos sritys, suprantamos kaip visuma: fizinè - puikus kūno ir jo organų funkcionavimas; protinè - gebėjimas surinkti ir pasinaudoti informacija; emocinè - jausmų supratimas ir tinkama išraiška; visuomenine - santykiai su savimi ir kitais; asmeninè - kiekvieno gebejjimas prisitaikyti prie pokyčių ir ịvairios aplinkos; dvasinè sveikata svarbi gyvybiškai bendrai sveikatos būklei, ji susijusi su žmogaus vertybėmis ir tuo, kas iš tikrujų rūpi (Petrauskienè, Zaborskis, 2000, p. 109).

Psichoanalizès pradininkas Sigmund'as Freud'as religines patirtis nagrinejjo remdamasis labiau psichiškai nesveikų žmonių išgyvenimais, bet jau ne vieną dešimtmetị mokslininkai atlieka tyrimus pirmenybę teikdami psichiškai sveikiems žmonėms. Išvados: tikejjimas pasitarnauja žmogaus brandai, darnai, motyvacijai, laimès pojūčiui ir sẻkmingam gyvenimui. Dabartinèje visuomeneje labiau vyrauja pesimizmas, nusivylimas, iš dvasios tuštumos kyla ịvairios priklausomybès. Parašyta daugybė mokslinių darbų, kokią ịtaką psichinei, visuomeninei, žmogaus fizinei sveikatai turi nepaviršutiniškas, gilus, nefanatiškas religingumas. Žmonèms patinka save apkrauti neigiamu mąstymu, kaltės jausmais, į tai juos šiek tiek stumia ir aplinka. Esminè tikẻjimo nuostata - žmogus nèra nei genų, nei aplinkybių kalinys ir gali keistis padedamas Dvasios, 
ịvairiose situacijose matydamas ne tik problemą, bet ir galimybę (cit. iš Dapšauskas, 2013). Mums nereikètų laimès apibrèžimo, jei atrastume vaistus nuo dvasinio skausmo, taigi dvasinè sveikata yra ypač svarbi.

Literatūroje, kur analizuojama ir aprašoma dvasinė sveikata, V. Juškienès ir I. Piktuižytès (2014) teigimu, dvasinė sveikata struktūruojama ị keturis asmenybės santykių lygmenis: santykị su savimi ir kitais žmonėmis, aplinka ir žmogų pranokstančia jẻga, transcendentiniu „Kitu“, kur kokybė yra tiesiogiai susijusi su dvasine žmogaus sveikata bei gerove.

Pozityviosios psichologijos tyrèjai skyrė šešias savybes, kurios teikia psichinę sveikatą ir gyvenimo pilnatvę. Psichologų teigimu, pagrindinès dorybès ir jas atitinkančios stipriosios charakterio pusès, užtikrinančios sveikatą ir suteikiančios laimę, yra:

- $\quad$ išmintis - kūrybiškumas, pomėgis mokytis, teisingas požiūris;

- teisingumas - socialinè atsakomybè, ištikimybè, lyderystė ir sąžiningumas;

- saikingumas, apimantis atleidimą, gailestingumą, nuolankumą, apdairumą, savikontrolę;

- drąsa - ištvermé, narsa, principingumas, gyvybingumas;

- žmoniškumas - meilè, gerumas ir socialinis intelektas;

- transcendencija - humoras, viltis, gèrejimasis grožiu ir dvasingumu, dèkingumas (Kheriaty, Cihak, 2017, p. 196-197).

Remiantis krikščioniškaja filosofija ir teologija, gerų charakterio bruožų ugdymas yra svarbus psichinei ir dvasinei sveikatai. Svarbiausios dorybès: išmintingumas, teisingumas, tvirtumas ir susivaldymas. Šv. Augustinas prie šių pridèjo dar tris, kreipiančias ị Dievą - tikèjimą, viltị ir meilę (Katalikų Bažnyčios katekizmas, 2012, nr. 1805-1829). Dvasinis gyvenimas šiuo metu vis labiau pripažistamas kaip integralus žmogaus veikimo pasaulyje ir jo savivokos aspektas, lemiantis žmogaus stabilumą ir teikiantis jëgų išgyvenant krizę, kai žmogus yra religingas (Žukauskas, Ramonas, 2015, p. 7).

Apibendrinant galima teigti, kad dvasinè sveikata - svarbiausia bendrosios sveikatos sudedamoji dalis, daranti ịtaką tiek fizinei, tiek emocinei sveikatai. Palaikyti fizinę sveikatą ir būti stipriam lengviau - čia padeda tinkama mity- 
ba, fizinis kūno lavinimas, o būti dvasiškai stipriam, tobulèti, priimti ịvairius pokyčius ne taip paprasta. Dvasiškai stiprūs žmonès lengviau susidoroja su krizėmis ir įveikia stresą. Tuo tarpu žmonėms, kurie stiprūs fiziškai, bet turi emocinių ir psichikos sutrikimų, kasdienybejje sunku užsitikrinti gerovę.

\section{Ligos ir krizès sąsaja}

Kai sergantis žmogus patiria neigiamus, slegiančius išgyvenimus, nesuranda išeities iš esamos padèties, galima sakyti, kad jis patiria krizę. „Psichologinè krizė apibréžtina kaip sveiko žmogaus reakcija ị sunkią ir reikšmingą jam emociškai gyvenimo situaciją, kuri reikalauja naujų adaptacijos ir ịveikimo būdų, nes turimų nebepakanka“ (Laurinaitis, Milašiūnas, 2008, p. 395). Kiekviena netektis mums primena, kad viskas turi pradžią ir pabaigą, praradimai yra mūsų gyvenimo kelionès dalis. Atsižvelgiant ị tai, su kokia netektimi susiduriame, anksčiau ar vèliau pasikeičia mūsų laiko išgyvenimo suvokimas, ,iš pradžiu ištęsdamas ir užpildydamas jị nerimu, gèla ir liūdesiu, o vẻliau nuolat primena mūsų laiko „čia ir dabar“" vertę ir prasmę“ (Polukordienè, 2008, p. 8). Netektys ištinka tada, kai žmogus praranda tai, kas jam brangu: miršta artimieji, išsiskiria šeima, netenkama darbo ar turto, prarandamas orumas ir garbė (Laurinaitis, Milašiūnas, 2008, p. 397), susiduriama su sunkia liga, netenkama sveikatos, prarandamas darbingumas. Netektis lydi gedejimas - laikas, kurio reikia, kad žmogus priimtų netektį, ją išgyventų ir su ja susitaikytų. İprasta gedèti artimiesiems mirus, visoms netektims, kurios susijusios ne tik su mirtimi, būtinas tam tikras laikas ir stadijos (Laurinaitis, Milašiūnas, 2008, p. 397).

Gyvenimui tekant ịprasta vaga, žmogus, sužinojęs apie sunkią ligą, išgyvena krizę: „Kriziniai išgyvenimai - tai krizinių ịvykių sukelti aštrūs, skausmingi, sunkūs žmonių jausmai - nerimas, baimè, psichologinis skausmas, pyktis, liūdesys, neviltis, kaltė ir pan. Krizinių išgyvenimų metu dažniausiai pasireiškia šių jausmų sumaištis ir krizę išgyvenančio žmogaus sutrikimas“ (Laurinaitis, Milašiūnas, 2008, p. 396). Psichologinès krizès trukmè - maždaug du mènesiai. Būsena nebevadinama krizine, jei per ši laiką žmogui nepavyksta grịžti ị kasdienio gyvenimo ritmą, nepraeina sunkūs išgyvenimai ir krizę lydintys jausmai. Tada nustatomi sutrikimai, kurie būdingi tokiais atvejais. 
Ypač stiprus krizinis išgyvenimas dèl pavojaus, susijusio su savo ar artimo asmens grèsme gyvybei, vadinamas psichologine trauma. Traumuojančiu laikomas ir krizinis ịvykis, kai žmogus pajunta, kad nuo jo nebepriklauso to ịvykio pasekmès. Psichologinių traumų atvejais būtina skubi psichoterapinè pagalba (Laurinaitis, Milašiūnas, 2008, p. 396-397).

Egzistencinès psichoterapijos požiūriu krizė suprantama kaip išgyvenamas skausmas ir naujų galimybių atsiradimas, krizès ir gyvenimas neatsiejami. Neigiamas išgyvenimas padeda pasiekti tai, kas pozityvu. Krizė - tai galimybe giliau išgyventi mirtį, laisvę, vienatvę, jas ịprasminti. Geštalto psichologijoje krizè yra lyg katarsinis išgyvenimas. Čia svarbus išsiverkimo veiksnys. Jei trūks raiškos, žmogus fiksuosis ties tuo išgyvenimu ir tai stabdys tolesnị augimą. Kalbant apie psichodinaminę sampratą krizinis išgyvenimas siejamas su vaikysteje patirtomis ir išgyventomis traumomis bei tuo metu susiformavusiais reagavimo būdais. Kognityvinè samprata byloja žmogaus reakciją ị traumuojantị ịvykị. Siekiant traumuojantị ịvykị pakeisti, didelis dèmesys skiriamas krizių prevencijai (Laurinaitis, Milašiūnas, 2008, p. 396).

Ivairių ligų, fizinių negalavimų kamuojamus žmones, sergančius nepagydomomis ligomis, prieš mirtị kamuoja skausmingi prisiminimai. Labiausiai žmonès pažeidžiami emociškai, tad geriausiai gyja atsidūrę akistatoje su savo mirtimi. Psichiatrė Elizabeth Kübler-Ross skyrè penkis emocinių žaizdų gijimo etapus: neigimą, pyktị, derẻjimąsi, depresiją ir prièmimą (Kübler-Ross, 2008, p. 53-173). Šios stadijos būdingos ir sunkiai sergant, mirštant, ir gydant skausmingus prisiminimus. Matome, kaip skirtingais atvejais - mirštant ir gydant prisiminimus - skiriasi nuostatų formulavimas (žr. 1 lentelę).

Gydomos emocinės žaizdos gyja panašiai kaip fizinès. Psichiatrai pripažista, kad bet kurią akimirką žmogus gali vertinti dvejopai: kaip dovaną, kuri padeda tobulèti, ir kaip žalojančią nelaimę (Linn, Linn, 2003, p. 18). Daugelị skausmingų dalykų po tam tikro laiko pajègiame vertinti kitaip ir ịvertinti, kuo mums tai buvo naudinga.

Apibendrinant galima teigti, kad krizè - slegiantis problemos subjektyvios reikšmès ir jai ịveikti turimų galimybių neatitikimas, kriziniai išgyvenimai - tai sunkūs krizinių ịvykių sukelti jausmai: nerimas, pyktis, baimè, neviltis, liūdesys. Sunkios ligos situacijoje žmogus išgyvena krizę, kai naujos 
1 lentelè. Penkios emocinių žaizdų gijimo stadijos

(remiantis Kübler-Ross, 2008, p. 53-173)

\begin{tabular}{|l|l|l|}
\hline \multicolumn{1}{|c|}{ Stadijos } & \multicolumn{1}{|c|}{ Mirštant } & \multicolumn{1}{c|}{ Gydant prisiminimus } \\
\hline Neigimas & $\begin{array}{l}\text { Neleidžiu sau net pagalvoti, kad } \\
\text { kada nors mirsiu }\end{array}$ & $\begin{array}{l}\text { Neleidžiu sau net pagalvoti, kad } \\
\text { kada nors buvau įskaudintas }\end{array}$ \\
\hline Pyktis & $\begin{array}{l}\text { Kaltinu kitus, kad jie leido } \\
\text { mirčiai mane sunaikinti }\end{array}$ & $\begin{array}{l}\text { Kaltinu kitus, kad jie mane skau- } \\
\text { dino ir žeidè }\end{array}$ \\
\hline Derëjimasis & $\begin{array}{l}\text { Keliu sąlygas, kurios turi būti } \\
\text { patenkintos, kol būsiu pasirengęs } \\
\text { mirti }\end{array}$ & $\begin{array}{l}\text { Keliu sąlygas, kurios turi būti } \\
\text { patenkintos, kol būsiu pasirengęs } \\
\text { atleisti }\end{array}$ \\
\hline Depresija & $\begin{array}{l}\text { Kaltinu save, kad leidau mirčiai } \\
\text { mane sunaikinti }\end{array}$ & $\begin{array}{l}\text { Kaltinu save, kad leidau būti } \\
\text { pažeidžiamas ir skaudinamas }\end{array}$ \\
\hline Priėmimas & Nekantriai laukiu mirties & $\begin{array}{l}\text { Nekantriai laukiu, kad iš } \\
\text { nuoskaudų išsivaduočiau } \\
\text { tobuleddamas }\end{array}$ \\
\hline
\end{tabular}

susiklosčiusios situacijos neįmanoma paneigti. Sunkūs kriziniai išgyvenimai dèl savo ar artimụjų gyvybès lemia psichologinę traumą. Egzistuoja penki emocinių žaizdų gijimo etapai: neigimas, pyktis, derejjimasis, depresija ir prièmimas. Šios stadijos būdingos ir sunkiai sergant, mirštant, ir gydant skausmingus prisiminimus. Tinkamai išgyventa krizè skatina asmenybės augimą.

\subsection{Krizę lydinti baimė ir neigimas}

Sergančio žmogaus krizė vis labiau riboja jo gyvenimą, tai susiję su baime, kuri užvaldo. Vyraujančios emocijos - baimè ir nusiminimas. Žmogus nepajègia grịžti prie ịprastos veiklos, baimè tuo metu yra nuolatinè palydovè. Galimi du krizès ịveikimo būdai: su ta būsena žmogus susitvarko pats arba susiranda žmogų, kuris jam padeda ịveikti baimę. Jei prie baimės priprantama ir situacija nesprendžiama - galimybė neišnaudota (Kast, 2006, p. 106). Baimę lydi neigimas. Nerimastingas diagnozès neigimas labiau būdingas žmonèms, kuriems per anksti arba labai netikètai pasakoma diagnozè, nepaisant jo pasirengimo. Neigdami ginasi kone visi sergantieji ir ligos pradžioje, 
ir vèliau. Kad liktų jẻgų gyventi, šie ligoniai neturètų nuolat galvoti apie mirtị (Kübler-Ross, 2008, p. 54).

Sunkiai sergantis žmogus ima savimi nepasitiketi, savęs nevertinti, jaučiasi bejègis. Jam susidaro ịspūdis, kad jis daugiau mažiau, o kartais ir išvis negali daryti jokios įtakos savo gyvenimui. Tokị žmogų būtina padrąsinti, nes ịveikti krizę reiškia ịveikti baimę. Pasireiškiantis destruktyvus, paralyžiuojantis, ị patị žmogų nukreiptas pyktis yra užsléptos baimės išraiška.

Baimè sunkios ligos (pvz., vėžio) atveju paprastai sutelkiama ị konkrečias situacijas - plaukų praradimą, gydymą, giminaičių baimę dèl ligos eigos ar kažką kitą. Šiuo atveju pabrèžiama ne pati mirties baimè. Natūralu, kad krizę išgyvenantis žmogus bijo mirties, būtina jam padèti, kad nenuvertintų savęs, savimi pasitikètų (Kast, 2006, p. 107). Kartu su baime atsirandantis neigimas paleidžia psichologinị savigynos mechanizmą, kai bandoma ịrodyti, kad tai, kas nutiko, nera blogai. Nuslopinamas ne tik skausmas, bet ir baimé, kylantis pyktis (Linn, Linn, 2003, p. 131). Neigimas tarsi sušvelnina netikètos, sukrečiančios žinios poveikị, leidžia ligoniui susikaupti ir imtis radikalios gynybos. Tačiau tai nereiškia, kad jis vèliau nenorès su kuo nors pasikalbèti apie artėjančią mirti, nejaus dvasinio palengvẻjimo (Kübler-Ross, 2008, p. 54).

Žmogui norisi, kad šioje bejègiškoje situacijoje atsirastų jam padedantis žmogus, kuris taptų autoritetu ir perimtų veiklą ị savo rankas. Kartais ši situacija išgyvenančiajam krizę sugrąžina jausmą, kad jis pats nekontroliuoja situacijos. Kilus grèsmei, kyla pavojus ir savivertei. Sudetinga atrasti gyvenimo prasmę, kai gyvybei kyla pavojus. Ir visgi prasmės reikia ieškoti, juk tokiu metu ypač svarbus likęs gyvenimo tarpsnis, kurio įprasminimas padeda išgyventi ligą (Kast, 2006, p. 109).

Krikščionišku požiūriu, kiekvieną kartą, kai išgyvename ligą galime: 1) pasakyti Kristui, ką jaučiame (plg. Lk 24, 13-24); 2) įsiklausyti, remdamiesi Šventuoju Raštu, ką Kristus jaučia (plg. Lk 24, 25-27); 3) degančia širdimi išgyventi Kristaus atsaką (plg. Lk 24, 32-35). Maldoje turètume apmąstyti, ką norime pakeisti, ko bijome. Klausytis širdimi, ne ausimis, leisti Kristui pripildyti širdị. Nebijoti ir atminti, kad Kristus visada su mumis (Linn, Linn, 2003, p. 138-150). 
Visi atsipalaidavimo metodai yra tinkami, siekiant sumažinti baimę, kuri pasireiškia fizine ịtampa. Baimė mus skatina ieškoti tikrumo, bet sunkia liga sergantị ligonị informuoti apie ligos eigą ne taip paprasta, siekiant nesuardyti taikomo gydymo eigos. Reikètų suvokti, kad mes daug ko gyvenime nežinome, todèl būtų prasminga su šia nežinomybe susitaikyti. Kalbètis su ligoniu apie baimę yra būdas ją ịveikti.

Apibendrinant kalbèjimas apie baimę, kuri kyla išgyvenant krizę, - vienas iš būdų ją ịveikti, nors būtent baimè neretai atima norą kalbètis. Deja, tai būdinga visoms pusèms - ir pacientui, ir gydytojui, ir artimiesiems. Kuo dažniau ligonis pasidalija savo jausmais, tuo mažiau jų paneigia, o ligos pradžioje neigdami ginasi visi sergantieji. Ligonio elgesị ir savijautą labai veikia su juo dirbančių darbuotojų reakcijos ir savijauta. Visi atsipalaidavimo metodai yra tinkami baimei, kuri pasireiškia fizine ịtampa, sumažinti. Pokalbis maldoje su Kristumi padeda ịveikti baimę ir priimti skaudžius pokyčius.

\subsection{Kančia ir vienatvė}

Kančia yra neišvengiama žmogaus gyvenimo patirties dalis. Kančios, nepasitenkinimo, prislègtumo priežastys gali būti susietos su aplinka, artimų žmonių santykiais, kančia priskiriama psichikos kategorijai (Auchter, Strauss, 2003, p. 78). Kančia - tai patyrimas, kuris pranoksta ligą. Labai kentèti galima net ir nesergant. Sergantis žmogus su kančia susiduria tiesiogiai. Apie ją paprastai vengiama kalbèti, nors ji mus lydi nuolat ir anksčiau ar vèliau su ja tenka susidurti. „Nèra tokios filosofijos ir tokios religijos, kuri nebūtų kẻlusi šio klausimo: iš kur, kodèl, - kad geriau ją suprastų, iprasmintų ir logiškoje gyvenimo vizijoje rastų jai vietą, padedančią ją priimti. Požiūriai ị kančią gali būti ịvairūs: antropologinis, medicininis, farmakologinis, filosofinis, religinis, psichologinis, kaip tik todèl, kad būdama išskirtinai žmogiška problema ji kreipiasi ị visas mokslo disciplinas, kurių objektas yra žmogus ir jo laimé" (Colombero, 2001, p. 28). Žmogaus gyvenimas gali atsiskleisti ir per kančią, ne tik per kūrybą ir džiaugsmą, ir tapti prasmingas.

Tuo tarpu dalis fizinio traumos gydymo - fizinis šokas. Nereikia kovoti su šiomis reakcijomis, tiesiog ligonį paguldyti ir sudaryti sąlygas, kad galètų laisvai 
kvėpuoti. Šoko atveju išsaugoma energija gyvybei palaikyti. Galimas ir emocinis neigimo šokas, ivvykus emocinei traumai, kuris taip pat reikalingas, kad atsistatytu emocinè sveikata. Nuo per didelio nerimo mus apsaugo neigimas, o tai gali apsunkinti mūsų grịžimą ị normalią būseną (Linn, Linn, 2003, p. 135). Žmogui susižalojus tam tikrus organus, patiriamas stiprus fizinis skausmas, kuris įspejja apie gresiantị pavojų - ribą. Skausmui paklūstame. Teigiamas skausmo vaidmuo yra fiziologinis veiksnys, leidžiantis lengviau diagnozuoti ligą. ,,Savigynos mechanizmais laikomos nesąmoningos reguliuojančios Ego funkcijos, kuriu svarbiausias tikslas - išstumti iš sąmonès pasitenkinimo neteikiančius afektus ir pojūčius. Pirmiausia ginamasi nuo baimès, paskui nuo liūdesio, sielvarto, depresijos, gèdos, kaltės pojūčio, pykčio ir agresijos“" (Auchter, Strauss, 2003, p. 138). Taigi, jeigu žmogui gresia pavojus neatsilaikyti prieš dirgiklius, kurie gali sutrikdyti psichikos pusiausvyrą, i̇ijungia apsauginiai mechanizmai. Dvasios gijimui naudingas ir saikingas neigimas, o per stiprus gali žaloti.

„Apskritai žmogus linkęs pervertinti tai, kokị atspalvị - teigiamą ar neigiamą, malonų ar nemalonų - igauna jo išgyvenimai. Svarba, kurią jis tam teikia, skatina nepagrịstai graudentis dèl likimo“" (Frankl, 2007, p. 160). Kančia žmoguje pažadina probleminius egzistencinius klausimus, kritinị žmogaus protą. Kenčiantis žmogus užduoda daug klausimų sau ir kitiems, nes pradeda tyrinèti save, nori žinoti, vis klausia, kodèl man, ką aš tokio padariau, kas kaltas, kas manimi rūpinsis, kada ir kuo tai baigsis, ar mirsiu, ar būsiu kitoks, kiek tai tęsis, kas man darosi, kuo pasitikèti ir t. t. Visi šie klausimai žmogų sukrečia, nes susiję su jo ateitimi: ne su tuo, ką jis turi, bet su siekiais, socialiniu tapatumu. Toks žmogus daug mąsto ir analizuoja.

Tikintieji, skaitydami ir gilindamiesi ị Bibliją, skirtinguose pavyzdžiuose gali įžvelgti ir tai, kaip kančios suvokimas priklauso nuo požiūrio ị situaciją. Senajame Testamente aprašyti atvejai, tikintiesiems suteikę laimès, o tiems, kurie neižzelgia Dievo veikimo per gyvenimo ịvykius, sukèlè dvasinę ịtampą. Dievas Tẻvas žinojo, kaip izraelitai bijojo netekti žemès, vaikų, laisvės. Savo testamente Izraeliui jis pažadejo žemès (plg. Pr 15, 18), vaikų (plg. Jer 31,$17 ; 2$ Sam 7, 12) ir išlaisvinti iš vergovès (plg. Iš 3, 7-12; 2 Sam 7, 11). Bet Dievas žinojo ir tai, kad būti be žemès, vaikų ir laisvès taip pat gali būti laimè. Pasiuntęs savo Sūnų, nedavẻ jam net vietos galvai priglausti, kad Jis 
priklausytų visoms tautoms (plg. Mt 8, 20), nedavė Jam vaikų, kad priklausytų kiekvienai šeimai (plg. Jn 17,21) ir suteikè vergo gyvenimą, kad Jis galètų mylèti atiduodamas save (plg. Fil 2, 7; Rom 5, 8). Pavyzdžiui neturto įžadus davę misionieriai liudija, kad beturčio gyvenimas suteikia laimès.

Suvokdami kančios prasmę priimame esamą tikrovę (Frankl, 2007, p. 161). Prieš 2005 m. Kalèdas popiežius Benediktas XVI Romos kurijoje kalbèjo apie kančios prasmę: „,Suprantama, mes turime padaryti visa, kad sumažintume kančią ir užkirstume kelią neteisybei, kuri yra nekaltujjų kančios priežastis. Kita vertus, turime taip pat atlikti viską, kad žmonès galètų atrasti kančios prasmę, kad pajègtų priimti savo kančią ir suvienyti ją su Kristaus kančia. Taip ji susilieja kartu su atperkančiaja meile ir dèl to tampa jèga prieš pasaulio blogi““(Benediktas XIV, 2006, p. 69).

Kalbant apie ligoni, ,,neveiklumas, ilgos vienatvès ir tylos valandos dieną ir naktį, tuščios ligoninès sienos, mažai pojūtinių dirgiklių, jų monotoniškumas, gèla, sukaustanti visą dèmesị ir nukreipianti jị ị skaudantị kūną, visa tai priverčia įeiti ị save ir vaikštinèti savo sielos takeliais $\langle$.. > . To, kuris kenčia, žodžiai niekada nebūna nei paviršutiniški, nei banalūs“" (Colombero, 2001, p. 28). Pasitaiko, kad žmogus pradeda vertinti gyvenimą tik iš tikrujuc kentedamas, išgyvendamas ligą atranda gyvenimo tikrąsias vertybes (Frankl, 2007, p. 166). Mūsų laikais, deja, paplitęs nepakantumas bet kokiai priklausomybei, ribotumui, negaliai ir senatvei. Taip pasireiškia neišvengiamų dalykų - kančios, senèjimo ir mirties - neigimas (Donnelly, 2012, p. 13). Daugelio saviraiškos būdas yra darbas, o liga ir kančia izoliuoja, tenka susitaikyti su priverstiniu neaktyvumu. Pasireiškia vienatvė, užsisklendimas: „Iprasta skausmu vadinti fizinę kančią, kylančią iš sergančio kūno, o moraline kančia - sielos kančią, kur vyrauja emocinis pradas. Ji daug sunkiau pastebima ir daug sunkiau gydoma, nei fizinè kančia, tačiau ji yra ne mažiau skausminga. Bet ar egzistuoja šios rūšies kančia, neatsispindinti organizme? < ..> Kiek žmonių serga vien dẻl to, kad per daug iškentejo!“(Colombero, 2001, p. 32). Kančia sukuria didžiulę įtampą, bet tik tada žmogus pajunta, ko apskritai neturètų būti. Tik likimo smūgių daužomas ir kančios įkaitintas gyvenimas igyja formą ir pavidalą (Frankl, 2007, p. 163-164). 
Žmogus tapatinasi su savo kūnu, gyvena jame. Per kūną žmogus pasirodo kitiems, pasauliui ir sau. Daugybė žmonių yra vien tik jų kūnas, bet kūnas esame mes. Jei blogai su juo elgsimès, galime susirgti, ne tik jaustis nelaimingi. Kūnas - konkreti mūsų buvimo pasaulyje vieta ir visa, kas jị menkina, stumia ị pavojų ir mūsų fizini gyvenimą šiame pasaulyje. Liga yra mūsų pačių, sudarytų iš dvasios ir kūno, vientisumo pažeidimas (Colombero, 2001, p. 33). Todèl sergantysis supranta kūno vertę, o sveikasis ne visada jị tausoja ir vertina.

Ligonis paprastai rūpinasi tik savimi. Todèl bendraujant su juo svarbu susitelkti ties pokalbiu su juo, patvirtinti, kad šiuo metu yra svarbus jo skausmas ir sveikatos susigrąžinimas. Skausmas labai susiaurina interesų ratą, ligonis, kuriam niekas neberūpi, kurio niekas nebedomina, vidumi jau yra miręs. Saugoti vidinę sveikatą, kaip ir ieškoti tiesos, yra darbas, kurio nę̨manoma atlikti vienam, tik drauge (Colombero, 2001, p. 35). Ligonis tyrinèja priežastis, kodèl tai atsitiko, ir padarinius, kurie gali ištikti jị bei jo artimuosius. Neretai susirgus susiaurẻja ligonių lankytojų ratas, nes dalis jų dẻl nežinojimo, kaip bendrauti su sergančiuoju, paprasčiausiai nutraukia bendravimą. Taip vienatvè mastas auga.

Šventasis tèvas Benediktas XVI yra sakęs: „Šis mūsų pasaulis yra baimių pasaulis: vargo ir skurdo baimės, ligų bei kančios baimès, vienatvės baimės, mirties baimès. Šiame pasaulyje turime labai išplètotą draudimų sistemą. Tačiau žinome, kad gilios kančios akimirkoje, paskutinejje mirties vienatvės akimirkoje joks draudimas negalės mūsų apsaugoti. Vienintelis vertingas šiu akimirkų draudimas kyla iš Viešpaties, kuris sako taip pat ir mums: „Nebijok, aš esu visada su tavimi.“ Galime kristi, bet galiausiai nukrisime ị Dievo rankas, o Dievo rankos yra geros rankos“" (Benediktas XVI, 2006, p. 66).

Kančioje yra riba, kurios negali peržengti nẻ vienas iš tų, kurie yra šalia, kad ir kaip norètųsi pagalbos arba koks stiprus bebūtų troškimas padèti. Paradoksalu, tačiau būtent sirgdami atrandame, kad kritiškiausiose situacijose niekas negali mūsų pavaduoti. Kiti gali kentèti su mumis, bet ne vietoj mūsų. Liga, agonija, mirtis įtraukia ir kitus žmones, tačiau neišvengiamai yra ir vienatvejje patiriamų įvykių, nes atsitinka slapčiausioje žmogaus gelmejje, kur niekas be Dievo negali pasiekti (Colombero, 2001, p. 38). Vienišumo bedugnè yra agonija, kur paskutinị žingsnị ligonis žengia vienas, nors pasirengusiųju ji palydèti ir daugiau. „Vien tik Viešpats, kuris gyvena mumyse ir yra 
mums artimesnis negu mes patys sau, gali mums padèti žengiant per šią sieną. < ..> Tikrasis mirties žiaurumas slypi jos išpuolyje prieš meilę ta prasme, kad mes suprantame gyvenimą kaip bendrystę, susivienijimą, o mirtis mus priverčia išsiskirti. Žmogui būdingas vienas esminis nepajègumas - pasidalyti, - tikraja to žodžio prasme, - su kuo nors savo jausmais“ (Colombero, 2001, p. 38). Deja, galime pasidalyti tik žiniomis, ne emocijomis, nes meilès, kančios ir džiaugsmo potyrio neįmanoma perteikti. Tai išsakyti reiškia tik bandymą tai apibūdinti, o apie tai kalbèti iš patirties gali tik tai išgyvenusieji.

Yra skirtumas tarp jausmo ir žinojimo. Čia būtina empatija. „Kančios akivaizdoje nepakanka intelekto. Galima žinoti viską apie skausmo fiziologiją, apie jo mechanizmus ir jo perdavimo kelius, tačiau nesuprasti, ką reiškia kentèti. Galima tobulai žinoti ašarų cheminę sudètị ir nesuprasti, kas yra verksmas. Mokslas apie žmogų yra išmokstamas, o žmones reikia perprasti““ (Colombero, 2001, p. 42). Ligoniui svarbu suvokti, kad geriausia stengtis gyventi laikantis ribų, kurias diktuoja liga, ir žinoti, kad energija, kuri skiriama įvairiems darbams atlikti, turi būti pamatuota (Donnely, 2012, p. 17). Apribojimuose reikètų įžvelgti galimybes ir neturèti labai didelių lūkesčių.

Sergant tyloje gimsta dialogas su savimi. Skausmas - tai kelias, kuris veda gilyn. Tai netolygu nekalbejjimui. Tai reiškia savyje susikurti erdvę, būti joje ir klausytis, atsiskyrus nuo visų kitų balsų. Kuo vyresnis ligonis arba kuo ilgiau jis serga, tuo labiau jaučia praeities ir ateities vertingumą. Laikas tada išgyvenamas pasitelkus atsiminimus. Prisiminimas tuo ryškesnis, kuo intensyviau buvo išgyventas ịvykis (Colombero, 2001, p. 43). Kenčiantysis neturi jokio veiksmų plano, nes kančią sukelia ịsitikinimas, kad nėra jokios išeities. Kenčiantys žmonès ne visada praranda viltị, kaip nutinka apatijos atveju (Zohar, Marshall, 2006, p. 86). Sunkaus ligonio tylèjimas gali būti ịvairus: tyli, nes susikaupęs permąsto svarbiausius gyvenimo momentus; tyli, nes išgyvena kančią, kartais atsisakydamas net paguodos, kuri svarbesnè už žodžius; tyli, nes yra praradęs viltị ir pavydi gerai besijaučiantiems žmonėms; tyli, ištikus pasidavusio žmogaus desperacijai; tyli, nes tetrokšta, kad viskas kuo greičiau pasibaigtų; tyli, nes yra vienišas žmogus, kurio niekas nelaukia; tyli, nes visą gyvenimą klausė kitų, neturèjo savo balso teisès. 
„Būna kurianti tyla, kurioje gimsta ir auga gyvybè, kuri tampa apreiškimu arba atradimu tiesų, kurios tiktai gyvenimo pabaigoje leidžiasi visiškai atskleidžiamos. Ramybè, kur yra kito prièmimas, bendravimas, pasidalijimas tuo, ką žmogus turi geriausio, noras kaskart vis parodyti meilę. Daugeliui tai yra malda - nuolanki širdies malda, tikroji mūsų malda. Tokia tyla yra adoracija“ (Colombero, 2001, p. 45). T. Soldavini (2011) pateikia nuostatas, kurios padeda kitaip išgyventi ligą ir kančią: sergant ir kenčiant dèkoti Švenčiausiajai Trejybei ir Ją garbinti; ligą ir kančią atiduoti Švenčiausiai Trejybei; sergant ir kenčiant melstis Švenčiausiajai Trejybei, pasitikint laukti pagalbos ir pagijimo (Soldavini, 2011, p. 149). Kančia ypač skatina melstis ir arteti prie Dievo, nes liga, agonija ir mirtis vyksta sąveikaujant su Dievu. Niekas taip žmogaus nepaskatina melstis, kaip skausmas. Kartais užejus ị ligonio kambarèli ar palatą tiesiog jaučiama pagarbos verta šventa tyla ir ramybė.

Taigi fizinę kančią sukelia sergantis kūnas, sielos kančią - emocinis pradas. Tikrasis kančios uždavinys ir siekis - neišvengiamas susidūrimas su tikrove. Sergant sunkia liga skausmas yra teigiamas fiziologinis veiksnys, padedantis diagnozuoti ligą, atliekantis įspejjamąją funkciją. Moralinès kančios prasmė, kai jau nustatyta diagnozè: žmogus ima vertinti savo kūną, o skausmas skatina žvelgti giliau, ị centrą, kur jis susitinka su pačiu savimi ir užsimezga dialogas. Būtent sirgdami suvokiame, kad kritiškiausiose situacijose žmogus lieka vienas. Tenka tai pripažinti. Liga, agonija, mirtis ịtraukia ir kitus žmones, vis dèlto tai yra neišvengiamai vienatvẻje patiriami ịvykiai, nes atsitinka slapčiausioje žmogaus gelmėje, kurios niekas, išskyrus Dievą, negali pasiekti.

\subsection{Pyktis ir kaltụjų ieškojimo etapas}

Skausmas, kančia tokie nepriimtini žmogui, kad tai tampa prievarta. Kyla klausimas, kas visgi kaltas dèl šios situacijos? Kartais nepagristai kaltinami artimieji, kiti žmonès, nes skausmas kietina širdị, apima neviltis, pasiduodama. Neretai kaltinamas Dievas. Kaip? Kodèl? Jei meldžiuosi, išklauso maldų, viską žino, mato, tai kodèl mane baudžia? Kuo nusikaltau? Kai skauda, Dievas tampa labai svarbus. 
Ligonis šiame emocinių žaizdų gijimo etape visur įžvelgia nuoskaudas. Lyg norètų visiems priminti, kad dar yra gyvas, nemirè. Sulaukęs dèmesio, pagarbos ir supratimo, paprastai nustoja pykti. Svarbu suvokti, kad ligonio pyktis nesusijęs su tais, ị kuriuos nukreiptas, tad atsakyti pykčiu reikštų tik naują pykčio bangą (Kübler-Ross, 2008, p. 67-68).

Pyktis - tai noras pakenkti ar blogio linkejjimas tam, kuris ịskaudino arba sutrukdè (Richmond, 2018, p. 15). Pyktis, kol yra neįsisąmonintas ir nuslopintas, nuodija gyvenimą. Galima išmokti slëpti pyktį ne tik nuo kitų, bet ir nuo savęs. Tokiu atveju kyla grėsmė tapti kritišku ir nekantriu, nes slopinant pyktị, jaučiama ịtampa, susierzinimas, nusivylimas, pažeminimas ir kt., pyktis gali pasireikšti nuolatiniu noru kažką keisti, kažką daryti geriau ir greičiau. Jei pyktis slopinamas gana ilgai, galimi fizinès sveikatos sutrikimai, tokie kaip opos, astma, padidèjęs kraujospūdis, neurodermitas, migrena, koronarinè širdies liga, psichikos ligos (Linn, Linn, 2003, p. 154). Normalu kartais pykti dèl to, kas prieštarauja mūsų įsitikinimams, vertybèms, sukelia skausmą, tai skatina keistis ir keisti tai, kas trukdo geriau gyventi. Pykti slepiant, gali pasireikšti depresiją sukelianti baimè.

Neigti pyktị yra nesveika ir gali pakenkti, pykčio jausmas - sveika reakcija i emocini pažeidimą. Paveikus save mylinčių žmonių emocijas, jie supyksta, o nemylintieji savęs puola ị depresiją, gali net nusižudyti. Todẻl psichoterapeutui svarbu paciento pyktį nukreipti teisinga linkme (Linn, Linn, 2003, p. 159-160). Nesvarbu, kas mus beskaudintų, mūsų viduje vidinis vaikas ima priešintis, sakyti, kad, jei tai nesiliaus, tuoj mirs. Situacijai pasikeitus, grižta ramybè, ima ryškèti ašarose skendintis pasaulis, pamažu gyvenimas grịžta ị ịprastas vèžes. Yra žmonių, kuriuos traukia aukos vaidmuo. Nesąmoningo troškimo kentèti motyvas - tai slaptas troškimas būti mylimam. Viltis, kad kiti, matydami kančią, susižavès, yra klaidinga (Richmond, 2018, p. 41-44). Tik suradę jègų ir pripažinę visas skaudinančias sielos žaizdas, prièmę pasaulị tokị, koks jis yra, neteisiantys, nereikalaujantys kantrieji atranda tikrają meilę.

Mūsų negebejjimas susidoroti su pykčiu, reagavimas yra vienas ligą lemiančių veiksnių. Daktaro Floydo Ringo iš Nebraskos universiteto (JAV) atliktas tyrimas atskleide, kaip reakcija ị pyktị veikia sveikatą. Jis apklausè 400 ligonių, sirgusių keturiolika ligų. Pacientui, buvusiam už širmos, jis 
15 min. uždavinèjo klausimus, kurie nesusiję su liga, ir iš atsakymų bandè nustatyti diagnozę. Klausimas, kuris greičiausiai padẻdavo diagnozuoti - „ką jūs darytumète, jei jums sėdint ant suoliuko, prieitų nepažįstamas žmogus ir i̊spirtų jums ị blauzdą?" Remdamasis atsakymais ị klausimą, mokslininkas teisingai ligą diagnozavo 87 procentams pacientų: 100 proc. tikslumu diagnozavo hipertireozę, 71 proc. - koronarinę širdies ligą, 83 proc. - skrandžio opaligę ir reumatoidini poliartritą, daugiau kaip 60 proc. - astmą, diabetą, hipertenziją, opinį kolitą. Atsakiusieji ypač griežtai buvo linkę sirgti koronarine širdies liga, degeneraciniu artritu ir skrandžio opalige; tie, kurie reaguotų neadekvačiai, t. y. nuslopintų pyktị, - neurodermitu, reumatoidiniu artritu ir opiniu kolitu; nevaržantieji savęs, kurie supranta, kad pyksta, bet retai tai parodo, linkę sirgti astma, diabetu, migrena, hipertenzija. Véliau psichiatrai apklausė ir sveikus žmones. Paaiškèjo, kad jie pripažįsta, jog pyksta ir suranda tinkamą pykčio išraiškos būdą (cit. iš Genienè, 2019). Tyrimas su išprovokuota pykčio situacija atskleide, kaip mūsų reakcija ị tam tikras stresines situacijas, pyktis priartina ligas, nes sudaromos tinkamos sąlygos joms atsirasti, apmaudas virsta fizinio kūno liga.

Stresą lemia atitinkama gyvenimo situacija, kuri retai išveda iš pusiausvyros būsenos, tačiau tam, kad išsivystytų streso išraiška, ši situacija turi būti suvokiama ir sąmoningai vertinama kaip įtempta (Гринберг, 2002, p. 100).

„Ateizmui žmogaus kančia, ypač nekaltujų ir vaikų kančia, visada buvo pagrindiniu ir stipriausiu jo argumentų ịrodymu, savo teorijos branduoliu. Ateistų požiūriu, niekas negali panaikinti Dievo nešlovès, kurią jis užsitraukia leisdamas, kad pasaulis kentètų, išskyrus tą faktą, kad jis iš viso neegzistuoja“" (Colombero, 2001, p. 48). Nemažai žmonių nesupranta, ką iš tikrųjų reiškia pasitikèjimas Dievu. Visišką pasitikèjimą Dievu sudaro du paskiri ir tarpusavyje susiję komponentai: pasitikejjimas Dievo teisingumu ir Jo apvaizda. Kad pasitiketume Dievo teisingumu, turime atmesti savo apmaudą, pyktį, keršto troškimą ir leisti Dievui vykdyti tobulą teisingumą pagal Jo valią. Pasitikèti Dievo apvaizda - tai nereiškia nieko nedaryti, bet tikèti, kad Dievas mus ves, saugos ir skatins prisiimti atsakomybę už savo gebẻjimų ugdymą ir panaudojimą atliekant savają tarnystę (Richmond, 2017, p. 181). Ligonio Dievui skiriami kaltinimai lieka be atsako, taigi nusimenama. Neretai ir pamaldūs žmonès jaučiasi išduoti ir kelia panašaus pobūdžio klausimus. 
Jėzus, mus išganydamas, vertino kančią. „Sugrąžinti kančiai sakralumą tai geriausias būdas ją ịprasminti ir sutrukdyti jai tapti sukilimu prieš Dievą ir desperaciją. Galbūt, užuot perẻjus prie beprasmiškų kelių, geriausias kelias duoti kančiai prasmę yra šis: tikèti, kad ji turi prasmę, net jeigu tai lieka nuo mūsų paslèpta. Jèzus nepaliko mums kančios filosofijos ar teologijos, kaip ją suderinti su mūsų laimès troškimu. <...> Galų gale ašaras nudžiovina ne supratimas, bet pasitikèjimas, atsidavimas, ir tikejjimas juo. Net ir jis meldèsi, kad kančia ir mirtis būtų nuo jo atitolintos. Tai pripažinimas nuolatinio gyvenimo atšiaurumo“ (Colombero, 2001, p. 49). Tikejjimas, kad galutinis žodis priklauso Dievui, jo valiai, veda ramybès link.

Taigi išgyvenant kančią kyla pyktis, neretai imamas kaltinti ir Dievas. Skausmas ir kančia yra nepriimtini žmogui, todèl reaguojama neigiamai. I situacijas, stresą, keliančius pyktį, reaguojame skirtingai. Šios reakcijos lemia tam tikrų ligų atsiradimą. İprasminti kančią labiausiai padeda tikèjimas, kad ji yra prasminga, net jei ta prasmè mums lieka neaiški. Padeda ne supratimas, o pasitikèjimas, atsidavimas, tikèjimas Dievu. Pasitikejjimas ir tikèjimas, kad galutinis žodis priklauso Dievui, suteikia ramybę.

\section{Išvados}

Krizè - slegiantis problemos subjektyvios prasmès ir esamų jos sprendimo galimybių neatitikimas. Kriziniai išgyvenimai - tai sunkūs krizinių ịvykių sukelti jausmai, tokie kaip nerimas, pyktis, baimè, neviltis, liūdesys ir pan. Susirgęs sunkia liga žmogus išgyvena krizę, kai naujos susiklosčiusios gyvenimo situacijos nebeįmanoma paneigti. Ypač sunkūs kriziniai išgyvenimai dèl savo ar artimujų gyvybės lemia psichologinę traumą. Tinkamai išgyventa krizė skatina asmenybès brandą. Niekas taip neskatina melstis ir neartina prie Dievo, kaip netektys, skausmas, ligos. Būtent tikejjimo stiprumas gali lemti, ar visiems kitiems aplinkui mirštant, žmogus išsaugos savo stiprybę. Maldos galia yra didžiulè, nuoširdžiai meldžiantis ji gali tapti, o neretai išbandymų laikotarpiu ir jiems pasibaigus tampa gyvenimo dalimi ir atrama.

Sergant fiziologiniai signalai padeda diagnozuoti ligą. Kai jau nustatyta diagnozè, žmogus ima vertinti savo kūną, o skausmas paskatina ị gyvenimą pažvelgti 
giliau, ieškoti vidinio dialogo su Dievu. Kančia paskatina melstis ir priartina prie Dievo, nes liga, agonija ir mirtis neatsiejamos nuo sąveikos su Dievu.

Sergantis ir dèl to kenčiantis žmogus neretai ima kaltinti Dievą, nes skausmas, kančia jam nepriimtini. İprasminti sergant kilusị sielvartą ir kančią padeda tikejjimas, kad liga turi prasmę, net jei tai sunku suvokti. Padeda ne supratimas, o pasitikejjimas, atsidavimas, tikejjimas Dievu. Pasitikejjimas ir tikejjimas, kad galutinis žodis priklauso Dievui, suteikia ramybę.

\section{Literatūra}

Auchter, T., Strauss, L. V. (2003). Psichoanalizès terminu žodynèlis. Vilnius: Vaga. Audickaitè, E. (2018). Visuomenès sveikatos stiprinimo koncepcijos formavimas visuomenès informavimo priemonèse (vakcinos nuo gimdos kaklelio vėžio atvejis). Magistro darbas. Kaunas: Vytauto Didžiojo universitetas.

Benediktas XVI. (2006). Dvasinés mintys. Vilnius: Katalikų pasaulio leidiniai.

Colombero, G. (2001). Vidinio išgijimo kelias. Vilnius: Katalikų pasaulis.

Dapšauskas, J. (2013). Apie dvasinę sveikata. Prieiga internete: <http://www.bernardinai.lt/straipsnis/2013-12-30-juozas-dapsauskas-apie-dvasine-sveikata/112146> [žiūrèta 2019-07-12].

Donnelly, N. (2012). Gyvenimas su liga ir kančia. Vilnius: Katalikų pasaulio leidiniai. Frank1, E. (2007). Sielogyda. Gydytojo rūpestis - siela. Vilnius: Vaga.

Genienè, V. (2019). Kad pyktis išeitu i gera. Prieiga internete: <http://valstietis.lt/ antra-kategorija/kad-pyktis-iseitu-i-gera> [žiūreta 2019-07-11].

Juškienè, V., Piktuižytė I. (2014). Dvasinès sveikatos samprata ir jos bruožai. Tiltai. Priedas: Mokslo darbai Nr. 45. Krikščioniškosios teologijos, kultūros ir tradiciju versmès, p. 30-49.

Juozulynas, A., Čeremnych, E., Kurtinaitis, J., Jankauskienė, K., Reklaitienė, R. (2005). Gyvenimo kokybè ir sveikata. Sveikatos mokslai, Nr. 1, p. 71-74.

Kataliku Bažnyčios katekizmas. (2012). Vilnius: Katalikų pasaulio leidiniai.

Kast, V. (2006). Gyvenimo krizès tampa gyvenimo galimybemis. Vilnius: Aldor.

Kheriaty, A., Cihak, J. (2017). Depresija. Atsiradimo priežastys, gydymas ir dvasine pagalba. Vilnius: Katalikų pasaulio leidiniai.

Kübler-Ross, E. (2008). Apie mirtį ir mirima. Vilnius: Katalikų pasaulio leidiniai.

Laurinaitis, E., Milašiūnas, R. (2008). Psichoterapija. Vilnius: Vaistu žinios.

Linn, D., Linn M. (2003). Gyvenimo žaizdu gydymas. Vilnius: Katalikų pasaulis.

Lowen, A. (2014). Depresija ir kūnas. Veiksmu planas. Vilnius: forSmart.

Medicinos enciklopedija. (1993). Vilnius: Mokslo ir enciklopedijų leidykla. 
Petrauskienè, A., Zaborskis, A. (2000). Aukime sveiki. Kaunas: Farmacija.

Pope John Paul II. (1996). Mentally Ill Are Also Made in God's Image. Prieiga internete: <https://www.ewtn.com/library/PAPALDOC/JP96N30.HTM> [žiūrèta 2019-07-12].

Richmond, R. L. (2018). Pyktis ir atleidimas. Vilnius: Katalikų pasaulio leidiniai.

Richmond, R. L. (2017). Sielos gydymas. Vilnius: Katalikų pasaulio leidiniai.

Soldavini, T. (2011). Viešpatie, išgydyk mane savo Meile. Vilnius: Kataliku pasaulio leidiniai.

State of Health in the EU. Lietuva Šalies sveikatos profilis 2017. (2018). Brussels: European Observatory on Health Systems and Policies.

Šventasis Raštas. (2000). Vilnius: Lietuvos Biblijos draugija.

Zittlau, J. ir kt. (2008). Didžioji namų vaistinè. Kaunas: Jotema.

Zohar, D., Marshall, I. (2006). Dvasinis kapitalas. Vilnius: Tyto alba.

Žukauskas, L., Ramonas R. (2015). Krikščioniško požiūrio į žmogu aspektai dvasiniame-psichologiniame konsultavime. Tiltai. Priedas: Mokslo darbai Nr. 1(46). Mokslo ir tikejjimo dialogai, p. 6-39.

Гринберг, Д. С. (2002). Управление стрессом. Санкт-Петербург.

\section{THEOLOGICAL AND PSYCHOLOGICAL BEHAVIOURAL ASPECTS OF THE ILL DURING THE DISEASE INFLICTED CRISIS}

\section{Remigijus Oželis}

Summary

In today's future, beauty and productivity-oriented culture, topics of death, illness, and loss are avoided, but every human life is inevitably accompanied by disease and loss. These experiences come together with spiritual pain, grief, tension, anxiety, fear and anger. If not addressed properly, these feelings cause physical and mental illnesses, loss of one's identity, psychological trauma and interfere with fulfilling relationships. On the other hand, this burden on the shoulders can help us grow spiritually. Spiritual health is the most important indicator of human health and the quality of life. It is also vital to the overall health of a person and is related to the essence of a human being. 
This article reveals the changes in the state of a person in the presence of disease from a psychological and theological perspective by analysing scientific literature, interpreting, systematizing information and studying the Bible, theological literature and information from other sources.

In the presence of a critical disease, when the life situation is no longer bearable, a person experiences a crisis. Extremely severe personal experiences, associated with a threat to their own lives or those of their loved ones, can lead to psychological trauma whereas a proper survival of a crisis promotes personal growth. It is argued in this work that strong faith can maintain inner personal vitality even during the most painful experiences. Suffering is not meaningless. Physical pain is a physiological signal that helps to diagnose a disease, while spiritual suffering leads towards an internal encounter with one's true self. Nothing strengthens human bond with God as much as major life challenges, because they happen in the unity with God.

Pain and suffering are unacceptable by people and God is often blamed in the face of these miseries. A patient in this situation would be saved and calmed by trust, devotion and faith in that the ultimate word belongs to God. The ill may be assisted by psychotherapy and prayer therapy, which must not be considered identical. 